\title{
A Comparison of Japanese and Turkish Mothers' Views about Self Care Skill Acquisition Age and Their Expectations from Preschools
}

\author{
M. Oya Ramazan ${ }^{1}$, Aya Sakai ${ }^{2}$ \\ ${ }^{1}$ Assist. Prof. Dr., Department of Preschool Education, Ataturk Education Faculty, Marmara University, Istanbul, Turkey \\ ${ }^{2}$ Aya Sakai holds an undergraduate and graduate degree in Turkey from Department of Preschool Education, Atatürk \\ Education Faculty, Marmara University, Turkey
}

Correspondence: M. Oya Ramazan, Assist. Prof. Dr., Department of Preschool Education, Ataturk Education Faculty, Marmara University, Istanbul, Turkey.

Received: January 5, 2017

doi:10.11114/jets.v5i3.2123

\author{
Accepted: February 6, $2017 \quad$ Online Published: February 22, 2017
}

URL: https://doi.org/10.11114/jets.v5i3.2123

\begin{abstract}
Spanning the vital temporal interval between birth and the elementary school education, the preschool period is one of the most critical times of human life due to its importance in the formation and nourishment of personality. Specifically the preschool education enables children to acquire and develop basic knowledge, skills and habits, thus shaping their social and emotional life, attitudes, beliefs and value judgments. Educational opportunities offered to children in this period facilitate the socio-cultural background for future life. The modern understanding of education designates that preschools are as important as families in providing children with the preliminary education during this period in life. Today, preschool attendance rates for children aged between five to six years (a year prior to starting school) are approximately $60 \%$ in Turkey and $97 \%$ in Japan. This demonstrates that Japan is significantly ahead of Turkey in the development and popularization of preschool education. Inquring into this discrepancy, this study compares the opinions of mothers, with different economic development levels and culture, on preschool period and education in Japan and Turkey. As such, 300 Turkish and 300 Japanese mothers were given a survey/questionnaire with 21 questions. The frequency and percentage of mothers' responses were calculated. The results indicate that Turkish and Japanese mothers had certain similar and certain different views. The answers given to nine questions inquiring the opinions of the Japanese and the Turkish mothers on self-care skill acquisition age yields that the Japanese mothers state that suggest that their children acquired self-care skills at earlier ages. When the answers given to the seven questions inquiring mothers' expectations from preschool education are examined, the results depict very differing opinions. However, based on the answer of the Japanese mothers in the sample, the study concludes that their children acquired self-care skills at a younger age. The questions about mothers' expectations from preschool institutions received different responses from Japanese and Turkish mothers.
\end{abstract}

Keywords: preschool education, expectations from preschools, Turkish mothers, Japanese mothers

\section{Introduction}

Children develop and change rapidly during the preschool period which can be considered the foundation of life. It is during this period that children gain their basic habits, start to socialize through various experiences, and advance their cognitive skills and talents. Preschool education may be defined as "a systematic education that ensures healthy development of children from birth to elementary school, sets the foundations for the development of a positive character, promotes creativity and self-confidence and involves educators and families by considering children's development levels, individual differences and talents" (Zembat, 2001). Opportunities and positive adult support offered to children during this period prepare children for life in the best way possible, while depriving children of these causes them to experience difficulties in the process of preparation for life (Oktay, 2002).

Hence, preschool education, which should be planned in a scientific and systematic way, are a crucial part of all educational systems (Ari, 2003). The relevant literature and practices in the field of contemporary education 55rproved that education should start at earlier ages to train qualified and healthy people who conform to the required behaviors (Zembat, Yildiz, Onder \& Fetihi, 1994).

In the preschool period, parents and preschool educators have great duties. To train healthy and modern generations, 
parents and educators in preschools should be in contact and know each other's expectations (Metin \& Ari, 1993). A cooperation between family and school allows teacher to know better the parents and child, and also allows parents to know school, program and teacher. Thus, parents have the opportunity to learn about the educational environment, and the conditions of school and teacher (Argon \& Akkaya, 2008). One of the factors that facilitate the spread of preschool education is elicited through parents' growing interest toward the preschool education.

The approximate preschool education rate of $60 \%$ in Turkey for five to six years old children (Aktan \& Akkutay, 2014) does not match the current development level of the country or the rate in developed countries. In Japan, which is a developed country with a different cultural and economic make-up to Turkey, the current preschool rate for five years old children is approximately $97 \%$ (OECD, 2011).

The obvious discrepancy between preschool attendees in Turkey and Japan is arguably the result of the different degrees of economic development in individual countries as well as the historical importance given to preschool education. Hence demonstrating how both countries had been approaching the preschool education is important to explicate the differences between their conceptions.

\subsection{Preschool Education in Turkey}

The historical development of preschool education in Turkey can be treated under two headings: "Ottoman Empire" and "Turkish Republic".

\subsubsection{Ottoman Empire Era}

Even though the empire did not have preschools in their current sense until the beginning of the 20th century, there were several schools that undertook the education of children in this stage. To illustrate, "sibyan" schools were elementary level schools but some parents also sent their younger children to these (Oktay, 1983a).

The opening of proper preschools in various provinces of the empire coincided with the period just before the Second Constitutional Period (1908) (Akyuz, 1996; Ozturk, 1998). The renowned educator Mustafa Sati opened a private kindergarten in Istanbul which quickly became a school for the children of rich families. This school offered education in light of the views of highly acclaimed educators such as Pestalozzi, Froebel, Montessori. Likewise, educator Kazim Nami Duru travelled to the Austro-Hungarian Empire during the Constitutional Period to observe schools that educated "kindergarten" teachers, and opened a kindergarten himself in Selonica on his return (Oktay, 2002).

Even though the Balkan Wars may have largely hampered these efforts, public kindergartens were also launched within the empire between 1913 and 1917. The biggest problems of both private and public kindergartens in this era was the difficulty of finding teachers educated in line with selected education methods (The Froebel method stood out among these) (Oktay, 2002). With the Temporary Elementary Education Law passed in 1913, certain legal arrangements were made in the field of preschool education. Item 3 of this law listed kindergartens and sibyan schools as elementary schools and Item 4 defined them as “institutions which contributed to children's physical and psychological development by offering them appropriate games for their age group, organizes trips, engages them in handcrafts, and involves discussions on psalms, patriotic poems and nature studies" (Ergin, 1977). The law also mentioned that kindergartens would be established for four to seven years old children and that new regulations are needed for these schools (Akyuz, 1996). In 1914, while the Ministry of Education budget was being drawn, money was set aside for opening kindergartens, and a total of 10 schools were planned for different parts of Istanbul that year (Oktay, 2002).

As a result of these regulations concerning preschool education, the number of kindergartens in big cities increased quickly; however, when the Ottoman Empire lost World War I with Mondros Ceasefire Agreement signed on October 30, 1918, most of it was conquered including the capital city of Istanbul (Akyuz, 1982). The one-year Kindergarten Teacher Education School opened by the state in 1915 in Istanbul was closed down in 1919, followed by the public kindergartens around the empire (Milli Egitim Bakanligi, 1993).

\subsubsection{Era of the Turkish Republic}

Between 1919 and 1922, Turkish people fought for their independence led by Atatürk, won their War of Independence, and finally proclaimed themselves a republic on October 29, 1923 and established the new Turkish state. After 1923, the country witnessed more important political, economic, legal, and cultural changes than ever (Akyuz, 1982).

In 1923 in Turkey, a total of 5,880 children were being educated in 80 preschools with 136 teachers (Yilmaz, 2003). However, the difficult circumstances of the country and the efforts spent on increasing literacy and creating a new type of citizen during the early years of the republic resulted in the majority of resources being spent on elementary schooling (Milli Egitim Bakanligi, 1993).

With two circulars issued on October 25, 1925, and January 29, 1930, schools were notified that the Ministry of Education would shift its kindergarten budget to elementary education, which resulted in the closing of the 
kindergartens which had been opened in the provinces (Ergin, 1977). However, owing to the statement in these circulars that "Kindergartens can only be opened in exceptional cases and in provinces with an adequate budget, for mothers who work in factories and fields and have no one to take care of their children while they are working", daycares were opened in Istanbul for the children of working class mothers (Oktay, 1983b). Consequently, preschool education was left to families and local authorities (Oktay, 2002).

The National Education Council, which is the highest advisory board of the Ministry of Education and discusses educational issues and makes recommendations, is also effective in the shaping of the Turkish education system (Ergun, 2008). Ever since 1939, 18 National Education Councils have been convened, some of which included preschool education on their agenda.

Item 6 of the Temporary Elementary Education Law which was effective in 1961 mandated that preschool education would be offered to those who demand it within elementary schools. Item 13 of the same law stated that preschools would educate children who did not yet reach compulsory school age, and that these could be opened by individuals, municipalities, local authorities and the state (Barkcin, 1991). The National Education Law of 1973 included preschool education within the formal education system and listed the scope, aims, and responsibilities of preschool education (Sapmaz \& Ilhan, 2008). In 1977, the "Preschool Branch" was established within the Ministry of Education General Directorate of Elementary Education (Yangin, 1991).

As social purposes had a major role in the opening of preschools in Turkey, laws and regulations issued by other ministries than education, particularly the Ministry of Health, also included resolutions about childcare for working women. With a law that passed in 1983, the Social Services and Child Protection Agency, which is affiliated with the Ministry of Health, was given the task of opening and inspecting childcare and education institutions for zero to five years old children. In addition, the Civil Servants Law guaranteed crèche and daycare centers within public institutions so that working mothers could be more efficient in the work place (Oktem, 1986).

The Ministry of Education's Preschool Branch which was opened in 1977 was reorganized in 1992 as the "General Directorate of Preschool Education" in order to better coordinate preschool education in Turkey and meet the increasing demand from the society (Yilmaz, 1992). This General Directorate was disclosed in 2013.

Today, preschool education in Turkey covers the education of pre-elementary children and is the first stage of the Turkish education system. Preschools can be established by private initiative or the state in line with the laws and regulations of the country, and are supervised by the relevant bodies of the Ministries of Education and Health. Preschools allow three to six years old children while kindergartens allow five to six years old children (the year prior to starting elementary school). Those affiliated with the Ministry of Health Social Services and Child Protection Agency includes crèches, daycare centers, children's clubs and children's houses. These admit zero to six years old children. The preschools opened by universities and large-scale work places for their employees may also be added to these. As can be seen from this classification, there are differences between the management, aims, programs and equipment of preschool institutions in Turkey (Oktay, 2002).

The Ministry of Education made preschool education compulsory for children between the ages of five and six (before the age at which they start school) in the 33 cities of Turkey, which has 81 cities in total, in 2009, and planned to make it widespread over the country. Moreover, it began to register all preschools under the Ministry of Education. Yet, the Ministry of Education of the same government released these studies in the year of 2013.

\subsection{Preschool Education in Japan}

The historical development of preschool education in Japan, can be divided into two main historical epochs: "Before World War II" and "After World War II".

\subsubsection{Before World War II}

In 1868, Japan saw the beginning of a new era known as the "Meiji", in which the administrators of the country supported the import of anything foreign which was deemed useful for a new Japan by official delegations sent to Europe and the US (Van Wolferen, 1992). Before the Meiji, the preschool children of samurai families used to be brought up by childminders, while the children of working class families that comprised the majority of the country were brought up by the elderly in the family and/or older siblings. The modern thought caused by the Meiji reform changed the traditional preschool education style in the country, and modern European preschool education ideology and techniques were imported to Japan (Kami \& Yamazaki, 1974).

With the support of the then Education Minister Fujimaro Tanaka, who saw the importance of girls' education and preschool education in a visit to the US, Tokyo Girls' Teacher Training School was established in 1875 and this was followed by the launching of a kindergarten within this school in 1876 (known today as the kindergarten of Oçanomizu Girls' University) (Yukawa, 2001). Serving the children of rich families, this school had three separate classes for three, 
four and five years old children with 40 children in each classroom. This paid school offered four hours of tuition everyday and followed Froebel's educational approach (Moriue \& Nozato, 2003).

After 1879, public kindergartens followed this very first kindergarten. In addition to the kindergarten of Sakurai Girls' School which opened in 1880, Christian missionary schools also started their own private kindergartens. However, these also served the children of rich families. By 1887, Japan had a total of 67 kindergartens: one state kindergarten, 52 municipality kindergartens and 14 private ones (Moriue \& Nozato, 2003).

In 1892, the first childcare institution affiliated with Niigata Sensyu School was opened by a farmer named Akazawa. After this, between the years 1890-1900, the care and education of poor urban children was mostly undertaken by kindergartens opened by Christians. In addition, childcare institutions started to open by work places in need of female work force such as thread factories or mines (Moriue \& Nozato, 2003).

In the earliest law concerning kindergartens, "Kindergarten Education and Learning Law", the Ministry of Education stated in 1899 that "children aged between three years and elementary school age are to be educated in kindergartens for a maximum of five hours per day by using the four main elements of 'games', 'songs', 'stories' and 'handcrafts'; and mentioned that the aim of preschool education was "to complement home education" (Yukawa, 2001).

Even though the number of kindergartens in Japan started to increase gradually after 1890, the government's emphasis on spreading elementary education stopped the number of kindergartens from growing in 1900. As a result, the number of private kindergartens exceeded that of public ones, which is still the case in Japan's kindergarten structure today (Moriue \& Nozato, 2003).

In 1900, "Futaba Kindergarten" was opened in Tokyo for the care and education of underprivileged children. Having long working hours, not complying with the existing law and receiving funding from the Ministry of Interior, this institution set an example for future childcare institutions in Japan (Tokyoto Shiritsu Youchien Kyoukai. 2000). With the Elementary School Practice Law of 1911, regulations concerning kindergartens were reconsidered by the Ministry of Education, and issues such as simplifying the educational characteristics of kindergartens, keeping kindergartens open for longer hours and class size were mentioned. The real aim of this rearrangement was to include the increasing number of kindergartens and childcare institutions for underprivileged children under the Ministry of Education; however, this aim could not be reached. Thus, the preschool education institutions of pre-World War I Japan were divided into "kindergartens" for upper and middle classes and "childcare institutions" for lower and working classes (Moriue \& Nozato, 2003).

World War I led to the sudden development of capitalism in Japan and increased the number of urbanized middle class people who started to support private kindergartens. In 1912, a total of 534 kindergartens existed in Japan, two of which were public institutions, 223 municipal institutions and 309 private institutions. In 1926, the total number of kindergartens doubled to 1066. Two of these were public institutions, 372 were municipal institutions and 692 were private institutions (Moriue \& Nozato, 2003).

Although the kindergarten-related chapter within the Elementary School Practice Law was separated in 1926 and turned into the free-standing "Preschool Education Law", its contents did not change significantly. The changes that were made concerned the addition of investigation to the four main elements of education, the need for obtaining an elementary education or further certificate to become a preschool teacher, and flexing school times and age limits (Moriue \& Nozato, 2003).

Even though kindergartens were said to spread and improve, the rate of schooling for five year olds was $6 \%$ in 1926 and only $10 \%$ in 1943, when schooling is accepted to be at its highest. This shows that until World War II, Japanese kindergartens remained as institutions attended only by the children of families at a certain economic level. The war constituted an increasing threat to the lives of people and necessitated the economy to rely on female work force, thus increasing the number of childcare institutions. While the proportion of kindergartens to childcare institutions was 2.26/1 in 1937, it became 1/1 in 1944. Owing to this balance, kindergartens and childcare institutions were intended to be combined but this did not happen when the war worsened. As cities also came under the threat of bomb attacks, an order was issued for all kindergartens in Tokyo to be closed down in April 1944, and preschool children were sent to live with relatives residing in safer places (Moriue \& Nozato, 2003).

\subsubsection{After World War II}

The defeated Japan had to completely overthrow its prewar systems and educational reform was one important change (Moriue \& Nozato, 2003). All personnel at the education directorate were educators from the USA and military officers. The duty of this directorate was to remove militarism and over-nationalism completely from the school system, and to implement new education models so as to educate youth for a democratic Japan (Cramer, \& Browne, 1982).

As most of the kindergartens and childcare institutions in cities had been burned down due to bombing, Japan's 
preschool education activities largely regressed after the war almost to their beginning point. While there were 2,006 kindergartens and 2,184 childcare institutions in 1943, after the defeat in the war (1946) the number of kindergartens fell to 1,303 and that of childcare institutions to 873 (Moriue \& Nozato, 2003).

According to the "School Education Law" that came into effect in 1947, kindergartens were accepted as schools; and according to the "Children's Social Help Law" that came into effect in 1948, childcare institutions were accepted as children's social help institution. The Children's Social Help Law reform of 1951 states "children to be admitted into childcare institutions are limited to those who do not receive enough care at home". With this reform, the distinct difference between the aims of kindergartens and childcare institutions were emphasized, which clearly divided Japanese preschool education into two as education-related kindergartens and care-related childcare institutions (Moriue \& Nozato, 2003).

The kindergarten attendance rate of $7.4 \%$ for five year olds in 1947 increased to $21.8 \%$ in 1955 . Believing that economic development would come from human skill, economists became interested in education, particularly early childhood education, and demanded that preschool education be improved. At the same time, the number of parents who wished to send their children to kindergarten also started to increase. As a result of the reforms, preschool education gained recognition and popularity among the public. To illustrate, the kindergarten attendance rate for five year olds was $28.7 \%$ in 1960, but $53.7 \%$ only 10 years later in 1970 (Moriue \& Nozato, 2003).

In 1963, the Ministry of Education declared the "First Kindergarten Education Popularization Plan". The Plan aimed for 3000 new kindergartens in seven years and a kindergarten attendance rate of $60 \%$ in all places with a population above 10 000. In 1963, the Ministries of Education and Health collaborated about kindergartens and childcare institutions, emphasized the functional differences between these two, and agreed that "the education offered in childcare institutions should have the framework of kindergarten education curriculum". Thus, equality was ensured between the educational content of kindergartens and childcare institutions (Moriue \& Nozato, 2003).

In 1971, the "Second Kindergarten Education Popularization Plan" was declared and more efforts were made to increase the kindergarten attendance rate of five years old children. Kindergartens were separated from elementary schools in 1972 to become independent, and attendance was encouraged by using the "kindergarten support system" to financially support families who sent their children to kindergarten. In 1976, the rate of five years old children attending kindergarten and childcare exceeded $90 \%$. Therefore, the majority of preschool children started elementary school after receiving a minimum of one year of education (Moriue \& Nozato, 2003).

Today, the education that three to five years old children receive in Japan is known as "preschool education" and is delivered by two different institutions: The "kindergartens" supervised by the Ministry of Education and "childcare institutions" supervised by the Ministry of Health and Labor. According to the Kindergarten Education Law, kindergartens only provide education; and according to the Childcare Institutions Law, childcare institutions offer both childcare and education. The education of children above three years is regulated by the Kindergarten Education Law (Monbukagakusho, 2004). In today's Japan, approximately 97\% of five years old children, 92\% of four years old children, and $70 \%$ of three years old children can receive preschool education (Youjihoiku Kenkyukai, 2004).

The analysis on the past and present conditions of preschool education in Turkey and Japan yields both similarities and differences. In the case of Japan a rapid economic development enabled the nation to allocate more funds into the development of the quality of education whereas Turkey lacked the adequate financial resources to follow a similar pattern. Such emphasis given to education Japan also enanbled the nourishment of the idea that preschool education is equally important.

With this background, this study compares the opinions of mothers residing in Turkey and Japan, on self care skill acquisition age and expectations from preschools.

\section{Method}

\subsection{Participants}

The participants are mothers of children between the ages of three and six who attend preschools under the Ministry of Education (12 in Istanbul, 15 in Osaka), in the neighborhoods where families at middle and high socio-economic levels live in Istanbul (Turkey) and Osaka (Japan). The number of mothers who were included in the study according to the principle of voluntariness was 600, including 300 Turkish mothers and 300 Japanese mothers.

\subsection{Procedure}

In this study, a survey/questionnaire with 21 close ended questions prepared by the researchers was administered to the mothers. The participating mothers were asked to mark the answer they find most appropriate for themselves.

The survey questions can be grouped under three titles according to their content (subject): 
1-Questions about mothers' personal information (Questions 1-5);

2-Questions about mothers' views about self-care skill acquisition age (Questions 6-14);

3-Questions about mothers' expectations from preschools (Questions 15-21).

The survey was translated into Japanese by the Japanese author who was also a former graduate student in Turkey. She sent the surveys to her friend, a teacher in Osaka and asked the surveys to be administered to mothers. Then, when she went to Osaka she collected the surveys and brought them to Turkey. In Istanbul, the surveys were brought to preschools by the researchers, and teachers were asked to give them to mothers who were voluntary. After a week, they were collected from schools.

\section{Findings}

The frequency and percentage distributions of the survey answers of 300 Turkish and 300 Japanese mothers were calculated. Since some questions were unanswered, the frequency and percentage for each question were subtracted from the number of mothers who answered the related question. The findings were grouped under three titles.

\subsection{Findings about the Personal Information of Turkish and Japanese Mothers}

This section includes the answers of Turkish and Japanese mothers who participated in the research to the five questions about their personal information (see Table 1).

Table 1. Frequency and Percentage Distributions of Japanese and Turkish Mothers' Personal Information

\begin{tabular}{|c|c|c|c|c|c|}
\hline \multirow{2}{*}{ Question } & \multirow{2}{*}{ Answer } & \multicolumn{2}{|c|}{ Japanese mother } & \multicolumn{2}{|c|}{ Turkish mother } \\
\hline & & $\mathrm{f}$ & $\%$ & $\mathrm{f}$ & $\%$ \\
\hline \multirow{6}{*}{ 1-Your age } & 20 years or younger & 1 & 0.3 & - & - \\
\hline & $21-25$ years & 3 & 1.0 & 16 & 5.3 \\
\hline & $26-30$ years & 22 & 7.4 & 44 & 14.7 \\
\hline & $31-35$ years & 125 & 41.8 & 123 & 41.0 \\
\hline & $36-40$ years & 112 & 37.5 & 91 & 30.3 \\
\hline & 41 years or older & 36 & 12,0 & 26 & 8.7 \\
\hline \multirow{4}{*}{ 2-Your education } & Elementary school graduate & - & - & 26 & 8.7 \\
\hline & Secondary school graduate & 6 & 3.8 & 12 & 4.0 \\
\hline & High school graduate & 55 & 34.6 & 92 & 30.7 \\
\hline & University graduate & 98 & 61.6 & 170 & 56.6 \\
\hline \multirow{5}{*}{$\begin{array}{l}\text { 3-How many children do } \\
\text { you have? }\end{array}$} & One & 55 & 18.3 & 151 & 50.3 \\
\hline & Two & 167 & 55.7 & 130 & 43.3 \\
\hline & Three & 70 & 23.3 & 17 & 5.7 \\
\hline & Four & 7 & 2.3 & 1 & 0.3 \\
\hline & Five & 1 & 0.3 & 1 & 0.3 \\
\hline \multirow{2}{*}{ 4-Are you working? } & Yes & 89 & 29.7 & 171 & 57.0 \\
\hline & No & 211 & 70.3 & 129 & 43.0 \\
\hline \multirow{2}{*}{$\begin{array}{c}\text { 5-Did you attend preschool } \\
\text { when you were a child? }\end{array}$} & Yes & 292 & 97.3 & 47 & 15.7 \\
\hline & No & 8 & 2.7 & 253 & 84.3 \\
\hline
\end{tabular}

One Japanese mother did not answer the first question. According to the answers given to the first question about the age of the mothers, almost the same percentage of Turkish mothers (41\%) and Japanese mothers $(41.8 \%)$ are between 31 and 35 years old. The second age group that Turkish mothers (30.3\%) and Japanese mothers (37.5\%).most frequently belong to is $36-40$.

The second question, which was asked to determine mothers' educational levels, was unanswered by 141 Japanese mothers. With regard to the educational levels of mothers who answered this question, $56.6 \%$ of Turkish mothers and $61.6 \%$ of Japanese mothers were graduated from two or four years universities, and $30.7 \%$ of Turkish mothers and $34.6 \%$ of Japanese mothers were high school graduates. There were 12 Turkish and six Japanese mothers who were secondary school graduates. On the other hand, while 26 Turkish mothers were elementary school graduates, no Japanese mothers were graduated from elementary school.

The answers given to the third question, which is posed to determine how many children mothers have got, demonstrate that $55.7 \%$ of Japanese mothers have two children and $50.3 \%$ of Turkish mothers have one child; and $23.3 \%$ of Japanese mothers have three children and $43.3 \%$ of Turkish mothers have two. There was one Turkish mother who has four children whereas seven Japanese mothers have four children.

The fourth question was about whether mothers had a job. According to the answers, 171 Turkish mothers (57\%) and 89 Japanese mothers (29.7\%) had a job. The number of Turkish and Japanese mothers who do not have a job is higher than those who have. 
The fifth question "Did you attend preschool when you were a child?" was answered "Yes" by 47 (15.7\%) Turkish mothers and 292 (97.3\%) Japanese mothers.

\subsection{Findings about the Views of Turkish and Japanese Mothers about Self Care Skill Acquisition Age}

This section depicts the answers given by Turkish and Japanese mothers to nine questions about their views on when preschool children acquire self-care skills (see Table 2).

Table 2. Frequency and Percentage Distributions of Japanese and Turkish Mothers' Views about Self Care Skill Acquisition Age

\begin{tabular}{|c|c|c|c|c|c|}
\hline \multirow{2}{*}{ Question } & \multirow{2}{*}{ Answer } & \multicolumn{2}{|c|}{ Japanese mother } & \multicolumn{2}{|c|}{ Turkish mother } \\
\hline & & $\mathrm{f}$ & $\%$ & $\mathrm{f}$ & $\%$ \\
\hline \multirow{6}{*}{$\begin{array}{l}\text { 6-At what age can a child put on shoes } \\
\text { without lace without anyone's help? }\end{array}$} & 2 years & 118 & 39.9 & 21 & 7.0 \\
\hline & 3 years & 120 & 40.5 & 106 & 35.5 \\
\hline & 4 years & 21 & 7.1 & 106 & 35.5 \\
\hline & 5 years & 6 & 2.0 & 50 & 16.7 \\
\hline & 6 years & 8 & 2.7 & 14 & 4.6 \\
\hline & After 6 years & 23 & 7.8 & 2 & 0.7 \\
\hline \multirow{6}{*}{$\begin{array}{l}\text { 7-At what age can a child dress without } \\
\text { anyone's help? }\end{array}$} & 2 years & 50 & 16.7 & 10 & 34 \\
\hline & 3 years & 170 & 56.7 & 72 & 24.2 \\
\hline & 4 years & 65 & 21.7 & 118 & 39.7 \\
\hline & 5 years & 13 & 4.3 & 80 & 26.9 \\
\hline & 6 years & 1 & 0.3 & 14 & 4.7 \\
\hline & After 6 years & 1 & 0.3 & 3 & 1.0 \\
\hline \multirow{5}{*}{$\begin{array}{l}\text { 8-At what age can a child eat without } \\
\text { anyone's help? }\end{array}$} & 2 years & 106 & 35.3 & 67 & 22.4 \\
\hline & 3 years & 144 & 48.0 & 125 & 41.8 \\
\hline & 4 years & 42 & 14.0 & 75 & 25.1 \\
\hline & 5 years & 8 & 2.7 & 29 & 9.7 \\
\hline & 6 years & - & - & 3 & 1.0 \\
\hline \multirow{6}{*}{$\begin{array}{l}\text { 9-At what age can a child wash hands } \\
\text { and face without anyone's help? }\end{array}$} & 2 years & 50 & 16.7 & 36 & 12.0 \\
\hline & 3 years & 156 & 52.2 & 125 & 41.7 \\
\hline & 4 years & 76 & 25.4 & 106 & 35.3 \\
\hline & 5 years & 13 & 4.3 & 28 & 9.3 \\
\hline & 6 years & 2 & 0.7 & 5 & 1.7 \\
\hline & After 6 years & 2 & 0.7 & - & - \\
\hline \multirow{6}{*}{$\begin{array}{l}\text { 10-At what age can a child brush teeth } \\
\text { without anyone's help? }\end{array}$} & 2 years & 26 & 8.9 & 30 & 10.0 \\
\hline & 3 years & 71 & 24.2 & 102 & 34.0 \\
\hline & 4 years & 68 & 23.2 & 117 & 39.0 \\
\hline & 5 years & 35 & 11.9 & 36 & 12.0 \\
\hline & 6 years & 19 & 6.5 & 13 & 4.3 \\
\hline & After 6 years & 74 & 25.3 & 2 & 0.7 \\
\hline \multirow{5}{*}{$\begin{array}{l}\text { 11-At what age can a child urinate } \\
\text { without anyone's help? }\end{array}$} & 2 years & 80 & 26.7 & 51 & 17.2 \\
\hline & 3 years & 164 & 54.7 & 137 & 46.1 \\
\hline & 4 years & 50 & 16.6 & 92 & 31.0 \\
\hline & 5 years & 5 & 1.7 & 17 & 5.7 \\
\hline & 6 years & 1 & 0.3 & - & - \\
\hline \multirow{6}{*}{$\begin{array}{l}\text { 12-At what age can a child defecate } \\
\text { without anyone's help? }\end{array}$} & 2 years & 33 & 11.0 & 15 & 5.0 \\
\hline & 3 years & 132 & 44.0 & 73 & 24.5 \\
\hline & 4 years & 83 & 27.6 & 94 & 31.5 \\
\hline & 5 years & 38 & 12.7 & 57 & 19.1 \\
\hline & 6 years & 9 & 3.0 & 41 & 13.8 \\
\hline & After 6 years & 5 & 1.7 & 18 & 6.0 \\
\hline \multirow{3}{*}{$\begin{array}{l}\text { 13-Five and six years old children can } \\
\text { protect themselves from risks. }\end{array}$} & Agree & 8 & 2.7 & 65 & 21.7 \\
\hline & Disagree & 243 & 81.0 & 167 & 55.9 \\
\hline & Undecided & 49 & 16.3 & 67 & 22.4 \\
\hline \multirow{3}{*}{$\begin{array}{l}\text { 14-Five and six years old children can } \\
\text { make decisions about themselves. }\end{array}$} & Agree & 35 & 11.7 & 100 & 33.8 \\
\hline & Disagree & 155 & 51.6 & 141 & 47.6 \\
\hline & Undecided & 110 & 36.7 & 55 & 18.6 \\
\hline
\end{tabular}

One Turkish mother and four Japanese mothers did not provide any answers to the sixth question which is: "At what age can a child put on shoes without lace without anyone's help?" The answers provide the following age interval and percentages. Japanese mothers chose the options "Two years" $(39.9 \%)$ and "Three years" $(40.5 \%)$ while Turkish mothers mostly chose "Three years" (35.5\%) and "Four years" (35.5\%).

The seventh question was not answered by threeTurkish mothers. This question "At what age can a child dress without 
anyone's help?" was answered "Three years" (56.7\%) and "Four years" (21.7\%) by the Japanese mothers, "Four years" $(39.7 \%)$ and "Five years" (26.9\%) by the Turkish mothers.

The eighth question was not answered by a Turkish mother. This question "At what age can a child eat without anyone's help?" was answered mostly "Three years" $(48 \%)$ and "Two years" $(35.3 \%)$ by the Japanese mothers, while Turkish mothers replied "Three years" (41.8\%) and "Four years" (25.1\%).

The ninth question was not answered by a Japanese mother. This question "At what age can a child wash hands and face without anyone's help?" was answered mostly "Three years" (52.2\%) and "Four years" (25.4\%) by the Japanese mothers, while Turkish mothers replied "Three years" (41.7\%) and "Four years" (35.3\%).

The tenth question "At what age can a child brush teeth without anyone's help?" was unanswered by seven Japanese mothers. Of the Japanese mothers who did reply, 25.3\% chose the alternative "After 6 years", 24,2\% chose "Three years", and $23.2 \%$ chose "Four years". On the other hand, 39\% of Turkish mothers replied "Four years", $34 \%$ replied "Three years", and $12 \%$ "Five years".

The eleventh question was unanswered by three Turkish mothers. This question "At what age can a child urinate without anyone's help?" was answered mostly "Three years" by Japanese mothers $(54,7 \%)$ and Turkish mothers $(46,1 \%$ ). $26,7 \%$ of Japanese mothers and $17,2 \%$ of Turkish mothers replied by saying "Two years", and 16,6\% of Japanese mothers and $31 \%$ of Turkish mothers replied by saying "Four years".

The twelfth question was unanswered by two Turkish mothers. This question "At what age can a child defecate without anyone's help?" was answered by Japanese mothers mostly "Three years" (40\%) and "Four years" (27.6\%), while Turkish mothers replied "Four years" (31.5\%) and "Three years" $(24.5 \%)$.

The statement "Five and six years old children can protect themselves from risks" in the thirteenth question was not answered by one Turkish mother, whereas $81 \%$ of Japanese mothers and $55,9 \%$ of Turkish mothers answered "I disagree". $16,3 \%$ of Japanese mothers and 22,4\% of Turkish mothers chose the option "Undecided".

The statement "Five and six years old children can make decisions about themselves" in the fourteenth question was not answered by four Turkish mothers, whereas $51,6 \%$ of Japanese mothers and $47,6 \%$ of Turkish mothers answered "I disagree". $36,7 \%$ of Japanese mothers chose the option "Undecided" and 33,8\% of Turkish mothers chose the option "I agree".

\subsection{Findings about the Expectations of Turkish and Japanese Mothers from Preschools}

This section includes the answers given by Turkish and Japanese mothers to seven questions about their expectations from preschools (see Table 3).

Table 3. Frequency and Percentage Distributions of Japanese and Turkish Mothers' Expectations from Preschools

\begin{tabular}{|c|c|c|c|c|c|}
\hline \multirow{2}{*}{ Question } & \multirow{2}{*}{ Answer } & \multicolumn{2}{|c|}{ Japanese mother } & \multicolumn{2}{|c|}{ Turkish mother } \\
\hline & & f & $\%$ & f & $\%$ \\
\hline \multirow{4}{*}{$\begin{array}{l}15 \text {-What is your reason to send } \\
\text { your children to preschool? }\end{array}$} & My child's general development & 236 & 79.5 & 263 & 87.9 \\
\hline & $\begin{array}{l}\text { To make my child ready for primary } \\
\text { school }\end{array}$ & 54 & 18.2 & 34 & 11.4 \\
\hline & There is none at home to care for my child & 6 & 2.0 & 1 & 0.3 \\
\hline & To provide my child's caring & 1 & 0.3 & 1 & 0.3 \\
\hline \multirow{3}{*}{$\begin{array}{l}\text { 16-There should be a strict } \\
\text { discipline in preschools. }\end{array}$} & Agree & 72 & 24.2 & 36 & 12.1 \\
\hline & Disagree & 112 & 37.7 & 240 & 80.8 \\
\hline & Undecided & 113 & 38.0 & 21 & 7.1 \\
\hline \multirow{3}{*}{$\begin{array}{l}\text { 17-Children should play out } \\
\text { every day in preschool in } \\
\text { winter and in summer. }\end{array}$} & Agree & 225 & 75.0 & 80 & 26.6 \\
\hline & Disagree & 24 & 8.0 & 182 & 60.7 \\
\hline & Undecided & 51 & 17.0 & 38 & 12.7 \\
\hline \multirow{3}{*}{$\begin{array}{l}\text { 18-Children should start learning } \\
\text { how to read and write in } \\
\text { preschool. }\end{array}$} & Agree & 152 & 50.8 & 85 & 28.5 \\
\hline & Disagree & 66 & 22.1 & 160 & 53.7 \\
\hline & Undecided & 81 & 27.1 & 53 & 17.8 \\
\hline \multirow{3}{*}{$\begin{array}{l}\text { 19-Children should start learning } \\
\text { add-subtract in preschool. }\end{array}$} & Agree & 95 & 31.7 & 209 & 69.6 \\
\hline & Disagree & 119 & 39.6 & 59 & 19.7 \\
\hline & Undecided & 86 & 28.7 & 32 & 10.7 \\
\hline \multirow{3}{*}{$\begin{array}{l}\text { 20-Children should start learning } \\
\text { foreign language in }\end{array}$} & Agree & 49 & 16.3 & 99 & 33.2 \\
\hline & Disagree & 137 & 45.7 & 161 & 54.0 \\
\hline & Undecided & 114 & 38.0 & 38 & 12.8 \\
\hline \multirow{3}{*}{$\begin{array}{l}\text { 21-Children should start learning } \\
\text { ccmputer in preschool. }\end{array}$} & Agree & 17 & 5.7 & 134 & 44.8 \\
\hline & Disagree & 195 & 65.0 & 126 & 42.1 \\
\hline & Undecided & 88 & 29.3 & 39 & 13.0 \\
\hline
\end{tabular}


The fifteenth question "What is your reason to send your children to preschool?" was not answered by three Japanese mothers and one Turkish mother. 87.9\% of Turkish mothers and 79.5\% of Japanese mothers answered "For my child's general development". Both Turkish (11.4\%) and Japanese mothers (18.2\%) preferred the answer "To make my child ready for primary school" at the second rank.

The statement "There should be strict discipline in preschools" in the sixteenth question was not answered by three Turkish and three Japanese mothers. The percentage of Turkish mothers who did not agreed this statement was $80.8 \%$, while the percentage of Japanese mothers was $37.7 \%$. 38\% of Japanese mothers and $7.1 \%$ of Turkish mothers chose the option "Undecided".

The statement "Children should play out every day in preschool in winter and in summer" in the seventeenth question $75 \%$ of Japanese mothers agreed this statement, whereas $60.7 \%$ of Turkish mothers did not agree this. $17 \%$ of Japanese mothers and $12.7 \%$ of Turkish mothers chose the option "Undecided".

The statement "Children should start learning how to read and write in preschool" in the eighteenth question was not answered by two Turkish mothers and one Japanese mother. 53.7\% of Turkish mothers disagree this statement, whereas $50.8 \%$ of Japanese mothers agreed this. $27.1 \%$ of Japanese mothers and $17.8 \%$ of Turkish mothers chose the option "Undecided".

The statement "Children should start learning add-subtract in preschool" in the nineteenth question $69.6 \%$ of Turkish mothers and $31.7 \%$ of Japanese mothers agreed this. $28.7 \%$ of Japanese mothers and $10.7 \%$ of Turkish mothers chose the option "Undecided".

The statement "Children should start learning foreign language in preschool" in the twenth question was not answered by two Turkish mothers. The percentage of Turkish mothers who did not agree with this statement was 54\%, while the percentage of Japanese mothers was $45.7 \% .38 \%$ of Japanese mothers and $12.8 \%$ of Turkish mothers chose the option "Undecided".

The statement "Children should start learning ccmputer in preschool" in the twentyfirst question was not answered by one Turkish mother. The percentage of Turkish mothers who did not agree with this statement was $42.1 \%$, while the percentage of Japanese mothers was 65\%. 29.3\% of Japanese mothers and 13\% of Turkish mothers chose the option "Undecided".

\section{Results and Discussion}

This study compares the opinions of mothers in Japan and Turkey on self-care skill acquisition age and expectations from preschools. The participants are mothers of children between the ages of three and six who attend preschools in the neighbourhoods of Istanbul and Osaka where families belonging to middle and high socio-economic segments reside 300 Turkish and 300 Japanese mothers were given a survey/questionnaire with 21 questions. The frequency and percentage of mothers' responses were calculated.

When the answers provided for the first five questions designed to gather personal information are examined, the result yields that the Turkish mothers were younger than the Japanese mothers and the majority of mothers were aged above 31 years. Turkish and Japanese mothers have higher educational levels, and that Turkish mothers' educational levels are higher than that of Japanese mothers. Almost half of the 300 Japanese mothers declined to give information about their educational status is a significant cultural difference, and the reason is thought to be tightly linked to them being not university graduates.

The number of Turkish mothers with single children was higher than their Japanese counterparts, while mothers preferred to have two children at most in both cultures. Among the 500 mothers included in the sample of a study held in Tokyo and Osaka in Japan, 18,4\% had one child and 68\% had two (Kyouiku Anket Chousa Nenkan Henshuiikai, 2005). Speculatively the mothers preference to having at least two children is due to the belief in the Japanese culture that a single child would be selfish, and a sibling is important to develop the ability of sharing. In Turkey, on the other hand, it is a known fact that the number of children that parents beget decreases in middle and upper socio-cultural and economic level families.

The percentage of working Turkish mothers was much higher than that of working Japanese mothers. This may have been due to the fact that Japanese work places do not prefer to employ married women with children and the preschools and caretakers for children under four years are expensive. Another reason may be that Japanese mothers with little children want to take care of their children themselves. Of the 500 mothers in the sample of Tokyo and Osaka, 69.3\% also stated that they did not want to work as their children were too little (Kyouiku Anket Chousa Nenkan Henshuiikai, 2005). Another noteworthy result is that despite their economic well-being, the majority of the Turkish mothers in the sample preferred to work. 
The fifth question "Did you attend preschool when you were a child?" was answered "Yes" by 47 Turkish mothers $(15.7 \%)$ and 292 Japanese mothers (97.3\%). Considering that most mothers in the sample were above the age 31, it can be seen that preschool education in Japan became widespread much before Turkey. Another study with 140 participant mothers from a culturally and economically similar country to Japan, South Korea and 139 mothers from Turkey concludes that $65.7 \%$ South Korean participants attended preschool when they were kids compared to $15.1 \%$ of Turkish mothers (Ramazan, 2015).

The answers given to nine questions inquiring the opinions of the Japanese and the Turkish mothers on self care skill acquisition age yields that the Japanese mothers state that suggest that their children acquired self care skills at earlier ages. According to these results, Japanese mothers seem to prefer giving responsibility to their children at earlier ages and encourage them to try regardless of any prospective mistakes to be made by their children or inability to finish the assigned task. A study conducted in Japan with 123 mothers who had three to six years old children, it was found that the $54 \%$ of three years old, $73,3 \%$ of four years old and $87,5 \%$ of five years old children were able to dress on their own without their mothers' help (Seikatsu Jouhou Center Henshuubu, 2004). In another study in Japan, a questionnaire was implemented on 1.148 mothers of kindergarteners in Osaka and 79,8\% replied that their children were able to eat on their own when they were three; $89,8 \%$ replied that they could eat on their own when they were four, and 96,3\% replied that they could eat on their own when they were five (Hanabara, 1995). Takeda (2002) states that in Japan, children can eat on their own at three, dress on their own at four, urinate on their own at three, and defecate on their own at four. Compared to the experience of the Japanese mothers, the Turkish mothers seem to act more over-protective and deem three-four years of age a more convenient time for the initiation of the development of sel-fcare skills in their kids. In the kindergarten curriculum prepared by the Turkish Ministry of Education for three to four years old children, the self-care skills acquisitions are listed as washing hands, face, and body properly, using the toilet, dressing and eating without help. This is in line with Turkish mothers' responses. Even though the responses obtained from Japanese and Turkish mothers on the statements "Five and six years old children could protect themselves from risks" and "Five and six years old children can make decisions about themselves" did not vary significantly, approximately half of the mothers did not agree with these statements.

When the answers given to the seven questions inquiring mothers' expectations from preschool education are examined, the results depict very differing opinions. The question "What is your reason to send your children to preschool?" was generally given the answer of "Child's personal development" by most of the Japanese and the Turkish mothers. The second most frequent answer was "To make my child ready for primary school." The results of another study conducted on 140 South Korean and 139 Turkish mothers is also in line with the results of the current study regarding the answers given to these questions (Ramazan, 2015). The goals that the Turkish education system aims to achieve through preschool education are (i) develop kids' general skills and (ii) to prepare kids for elementary school. Thus, the answers of the Turkish mothers appear to correlate with the objectives of the Turkish education system. A study conducted in Turkey concludes that the parents prioritze the development of necessary academic skills than the nourishment of socio-emotional skills in preschool years (Simsek \& Ivendi, 2014). Aktas's (2002) research outlines the parents' expectations from preschools as follows: Teaching social behavior skills, solving the problems amenable to kids' age and development, and preparing kids for elementary school. Another study in Turkey also concludes that the top item in mothers' expectations from preschool institutions is the development of social skills (Sevinc, 2006).

The statement "There should be strict discipline in preschools" in the sixteenth question received negative responses from most of the Turkish mothers $(80.8 \%)$ whereas the disagreeing Japanese mothers were only $37.7 \%$ of total Japanese mothers. The figure of undecided Japanese mothers was 38\%. In this question, the term "discipline" was used by the researcher in the sense of teaching certain habits and preparing children to live in harmony personally and socially within the limits of rules. The reason that a great number of Turkish mothers did not agree with this statement may be the result of their different conceptions regarding the term discipline. In Turkey, the word discipline connotes that the behavior toward children that includes punishment. In another study done in Japan, it was found that $75 \%$ of women who had children in preschool period prioritize the development of discipline (Seikatsu Jouhou Center Henshuubu, 2004). A study done with 320 Japanese and 340 German mothers who had children between the ages of three and five years old showed that their primary expectation from preschool education was that their children should learn to behave in conformity with society and develop such behavior as a habit. In a study held in 2003 in Japan, $75 \%$ of 1,428 mothers who had preschool age children stated that discipline was the most important issue for them in their children's education (Youjihoiku Kenkyukai., 2004). In a study done with South Korean and Turkish mothers, the percentage of Turkish mothers who did not agree with the opinion that "there should be a strict discipline in preschools" was $68,3 \%$, whereas it was $74,3 \%$ in South Korean mothers (Ramazan, 2015). This study also concludes that the Turkish mothers and the South Korean mothers have the same opinions.

While $75 \%$ of Japanese mothers agreed with the question 17 that "Children should play out every day in preschool in 
winter and in summer", only $26.6 \%$ of Turkish mothers agreed with it. The percentage of undecided Japanese and Turkish mothers was similar. In a study done with 140 South Korean and 139 Turkish mothers, the percentage of Turkish mothers who did not agree with the same statement was $66.2 \%$, whereas it was $30.7 \%$ in South Korean mothers (Ramazan, 2015). Many previous studies have shown that Turkish mothers are overprotective. The results of this study also corroborate this finding. In another study done in Japan, 91 mothers who had children between the ages of three to five were asked the question "What are your expectations from preschools?". The answer "Doing sufficient physical activities and develop a healthy body through playing games" was chosen at the second rank (Fuganaga, 1997). The places where children can move sufficiently and freely are often places out, therefore when children are not allowed to go out due to cold or hot weather or rain, they will not be able to release their energy, and their physical and psycho-motor development will not reach the desired level.

$50.8 \%$ of the Japanese mothers agreed with the statement that "Children should start learning how to read and write in preschool" in question 18 , while only $28.5 \%$ of Turkish mothers did so. Those who were undecided consist of $27.1 \%$ of Japanese mothers and $17.8 \%$ of Turkish mothers. These views of Japanese mothers may be attributed to the belief that preschools should prepare children for elementary education as well as the high expectations of schools and society from students. In a study with newcomers in the first grades of 10 elementary schools in Tokyo, it was found that 87.8\% of the children could read the Japanese script and $48.8 \%$ could write it (Suda, 1980). In a study done with 140 South Korean and 139 Turkish mothers, the percentage of Turkish mothers who did not agree with the same statement was 47.5\%, whereas it was only 5.7\% in South Korean mothers (Ramazan, 2015). The Turkish preschool curriculum prepared by the Ministry of Education and used in the preschools feature pre-studies of learning how to read and write, but does not include teaching how to read and write. The answers of Turkish mothers indicate that they acknowledge what curriculum entails accept it. The reason why the Japanese and Korean mothers have expectations regarding this may be tied to the difficulty of learning how to read and write in their respective languages.

$31.7 \%$ of Japanese mothers and $69.6 \%$ of Turkish mothers agreed with the statement in question 19, "Children should start learning add-subtract in preschool". As mathematics is a course that most students fear and fail in the Turkish educational system, Turkish mothers who were against the teaching of reading and writing may have agreed more with the teaching of basic mathematical operations. In the study done with South Korean and Turkish mothers, the percentage of Turkish mothers who did not agree with the same statement was $20.9 \%$, whereas it was only $4.3 \%$ in South Korean mothers (Ramazan, 2015).

A similar percentage of Turkish (54\%) and Japanese mothers (45.7\%) did not agree with the statement in question 20 that "Children should start learning foreign language in preschool". In a previous study conducted in Japan in 2005, only $28.7 \%$ of 821 mothers who had four to six years old children stated that they wanted their children to start learning English before elementary school (Kyouiku Anket Chousa Nenkan Henshuiikai, 2005). The results of both studies suggest that Japanese mothers do not have many expectations about foreign language instruction in the preschool period. On the other hand, the importance of learning a foreign language in Turkey may have raised Turkish mothers' expectations about the early exposure to foreign languages in preschools. In the study done with South Korean and Turkish mothers, the percentage of Turkish mothers who agreed with the same statement was $76.3 \%$, while it was $88.6 \%$ in South Korean mothers (Ramazan, 2015).

The percentage of the Turkish mothers who did (44.8\%) and did not agree (42.1\%) with the statement 21 that "Children should start learning computer in preschool" was similar. On the other hand, 65\% of the Japanese mothers did not agree. This may be attributed to the fact that Japan is one of the most technologically advanced countries in the world, technology is used commonly in every walk of life, and computers are thought to be hazardous. The results of a study which compared the preschool education systems in Japan and the Asian countries of Korea, China, Taiwan, Betnem, Thailand, Malaysia, Singapore, India, and the Philippines demonstrate that, in contrast to elementary school courses, Japanese preschool education attempts to develop the qualities of personality, senses and human body to children via nature and games. In the other countries listed above, subjects such as mathematics, foreign languages and computers are included in the preschool curriculum and offered as courses (İkeda \&Yamada, 2006). In the study done with South Korean and Turkish mothers, the percentage of Turkish mothers who agreed with the same statement was 50.4\%, while it was $66.4 \%$ in South Korean mothers (Ramazan, 2015).

\section{References}

Aktan, O., \& Akkutay, U. (2014). Preschool education in OECD countries and Turkey, Asian Journal of Instruction, 2(1), 64-79.

Aktas, A. Y. (2002). Parents' attitudes towards preschool education and preschools. Journal of Institute of Social Sciences, Cukurova University, 10(10), 24-36

Akyuz, Y. (1982). Turkish education history. Faculty of Political Sciences, School of Press and Publication. 
Akyuz, Y. (1996). The establishment and development of preschools in Turkey, Journal of National Education, 132, 11-17.

Argon, T., \& Akkaya, M. (2008). Parents' views about preschool education and preschool institutions, Kastamonu Education Journal, 16(2), 413-430.

Ari, M. (2003). Preschool education in Turkey and the importance of quality) In M. Sevinc (Ed.), Development in Childhood and New Perspectives on Education. Istanbul: Morpa Yayincilik (Publications), 31-35.

Barkcin, F. (1991). DTP studies and the place of preschool education in five tears development plans, 7th $\mathrm{Ya}-\mathrm{Pa}$ Preschool Education and Widespreading Seminar Book, 18-23.

Cramer, J. F., \& Browne, G. S. (1982). Modern education) (Cev. F. Oguzkan). Istanbul: Milli Egitim Basimevi (Press).

Ergin, O. (1977). Turkish education history. Istanbul: Eser Matbaasi (Eser Print).

Ergun, M. (2008). Legal regulations on education), Turkish Educational System and School Administration. Ankara: Pegem Akademi, 18-46.

Fukunaga (1997). On the life of kindergartners: What are they really like at home? Research Reports, 42(2), Himeji College of Hyogo Published.

Hanabara, S. (1995). A study on the daily behavior of children. Report 1 (The formation of the basic behavioral pattern proses and discipline). Shingaku to Jinbun, 35. Osaka: Osaka Christian College.

Ikeda, M., \&Yamada, C. (2006). Ajia no syugakumae kyouiku. Early Childhood Education in Asia System, Curriculum and Practices. Tokyo: Akasi Shoten.

Kami, S., \& Yamazaki, T. (1974). Nihon no youchien. Youjikyouiku no rekishi. Tokyo: Rinrisha.

Kyouiku Anket Chousa Nenkan Henshuiikai. (2005). Kyouiku anket chousa nenkan ge. Tokyo: Souikusha.

Metin, N., \& Ari, M. (1993). Parents' expectations from preschool institutions. 9th Ya-Pa Preschool Education and Widespreading Seminar Book. Istanbul: YAPA Yayinlari (Publications).

Milli, E. B. (1993). Preschool education. The Ministry of National Education General Directorate Publication.

Monbukagakusho. (2004). The Monthly Journal of Monbukagakusho, 1545. Tokyo: Gyousei.

Morita, Y., \& Kondo, Y. (1986). A survey study on rearning behavior and attitudes of mother of Japan and West Germany. Osaka: Memoirs of Shijonawate Gakuen Women's College, 20.

Moriue, S., \& Nozato, F. (2003). Shotou kyouiku genri. Tokyo: Kouseikan.

OECD (2011). Education at a glance. Retrieved from https://doi.org/10.1787/eag-2011-en

Oktay, A. (1983a). Preschool education in the past and today in Turkey). Journal of Education and Science, 7.

Oktay, A. (1983b). Preschool education and its problems. A General Overview on Preschool Education. Ankara: Turk Eğitim Dernegi Yayinlari (TED Publications).

Oktay, A. (2002). Yasamin sihirli yillari: Okul oncesi donem (The magical years of life: Preschool period). Istanbul: Epsilon Yayincilik (Publication).

Oktem, T. (1986). Preschool education studies in General Directorate of Social Services and Child Protection Institute. 4th Ya-Pa Preschool Education and Widespreading Seminar Book, 20-23.

Ozturk, C. (1998). Institutions to train teachers in Turkey in the past and today. Marmara University, Ataturk Education Faculty Publications.

Ramazan, O. (2015). A comparison of Turkish and South Korean mothers' views about preschool education and their expectations from preschools. US-China Education Review B, (5) 9, 565-578.

Sapmaz, M., \& Ilhan, A. (2008). National education regulation. Istanbul: Net Yayin, Dagitim, Pazarlama (Net Publication, Distribution, Marketing).

Seikatsu Jouhou Center Henshuubu (2004). Kosodate, kyouiku, kodomono kurashi detashu. Tokyo: Seikatsu Jouhou Center.

Sevinc, M. (2006). The expectations of mothers who have children attending preschools. Journal of Kazim Karabekir Education Faculty, 13, 218-225.

Simsek, Z. C., \& Ivrendi, A. (2014). Expectations of parents from preschools. H.U.Journal of Education, 29(2), 240-254. 
Suda, K. (1980). Kahamoji no oshiekata. Method of Teaching Hiragana. Tokyo: Mugi Shiobou.

Takeda, K. (2002). Fundamental living habits. Youji Kyouiku Joho Handbook. Tokyo: Koreeru Sha.

Tokyoto Shiritsu Youchien Kyoukai. (2000). Shin youchien sankousho. Tokyo: Freeberu Kan.

Van Wolferen, K. (1992). The secrets behind Japanese power. Ankara: Turkiye Is Bankasi Kultur Yayinlari (Publications).

Yangin, E. (1991). Preschool education in Turkey. 7th Ya-Pa Preschool Education and Widespreading Seminar Book, $9-12$.

Yilmaz, N. (1992). Early childhood development and preschool education project. 8th Ya-Pa Preschool Education and Widespreading Seminar Book, 11-12.

Yilmaz, N. (2003). Preschool education in Turkey. In. M. Sevinc (Ed.), Early Childhood Development and New Perspectives on Education. Istanbul: Morpa Kultur Yayinlari (Publications), 12-17.

Youjihoiku, K. (2004). Saishin hoiku shiryoshu. Tokyo: Mineruba Shobou.

Yukawa, (2001). Nihon youchien seiritsushi no kenkyu. Tokyo: Kazama Syobou.

Zembat, R. (2001). An analysis of preschool institutions with regard to quality. Marmara University, Atatürk Education Faculty Publications.

Zembat, R., Yildiz, G., Onder, A., \& Fetihi, L. (1994). An analysis of programs used in preschool institutions in Istanbul. 10th Ya-Pa Preschool Education and Widespreading Seminar Book, Istanbul: Ya-Pa Yayinlari (Publications).

\section{Copyrights}

Copyright for this article is retained by the author(s), with first publication rights granted to the journal.

This is an open-access article distributed under the terms and conditions of the Creative Commons Attribution license which permits unrestricted use, distribution, and reproduction in any medium, provided the original work is properly cited. 